\title{
A Methodology to Detect and Quantify Five Pathogens Causing Potato Tuber Decay Using Real-Time Quantitative Polymerase Chain Reaction
}

\author{
Z. K. Atallah and W. R. Stevenson
}

Department of Plant Pathology, University of Wisconsin, Madison 53706.

Accepted for publication 28 April 2006.

\section{ABSTRACT}

Atallah, Z. K., and Stevenson, W. R. 2006. A methodology to detect and quantify five pathogens causing potato tuber decay using real-time quantitative polymerase chain reaction. Phytopathology 96:1037-1045.

Late blight (Phytophthora infestans), pink rot (Phytophthora erythroseptica), leak (Pythium ultimum), dry rot (Fusarium sambucinum), and soft rot (Erwinia carotovora subsp. carotovora and subsp. atroseptica) are particularly damaging diseases of stored potato tubers worldwide. In this study, we present a methodology to detect and quantify the causal agents of the five aforementioned diseases from whole potato tubers, using real-time quantitative-polymerase chain reaction. Six primer pairs were designed to amplify targets smaller than 150-bp DNA in single copy protein-coding gene targets of each of the pathogens and the potato host.
Using a large collection of pure culture DNA samples, all primer pairs specifically detected the DNA target in the intended pathogenic species. Amplification efficiencies over a five-log dilution series ranged between 95 and $100 \%$ and were unaffected by the presence of large amounts of host DNA. The detection level of the primers reached $0.5 \mathrm{pg}$ of target DNA. Pathogens were detected in $100 \mathrm{pg}$ of total DNA extracted from 170 to $250 \mathrm{~g}$ of tubers, 4 days after inoculation, regardless of the presence of symptoms. The presence of $P$. erythroseptica, Pythium ultimum, or E. carotovora was also detected in $1 \mathrm{ng}$ of DNA extracted from potato tubers collected from a commercial storage facility. This study provides the first step in a methodology to predict the storability of potato tubers following harvest.
Postharvest potato (Solanum tuberosum) losses due to plant pathogens in Wisconsin exceeded $\$ 9$ million for the 2000 and 2001 stored crops (1). Crops grown during those years experienced above average rainfall and unseasonably warm conditions during harvest and early storage. Such conditions are highly favorable for pathogen dispersal and disease occurrence. Losses in some individual storage facilities exceeded $20 \%$. Nationally, potato storage losses in the United States amounted to 1.3 to 1.9 million tons ( 30 to 42 million hundred weight $\approx 100 \mathrm{lb}$ or 45.4 $\mathrm{kg}$ ) annually between 1999 and 2001, equivalent to 8 to $9 \%$ of the total annual potato production, representing more than $\$ 200$ million (1).

Multiple pathogens are capable of infecting potato tubers at various stages through the course of the growing season, at harvest and during handling and storage, and cause a variety of symptoms on the tuber periderm and internal tissues. The most notable oomycetes and fungi that cause tuber rots include Phytophthora infestans (late blight), Phytophthora erythroseptica (pink rot), Pythium ultimum var. ultimum (leak), and Fusarium sambucinum (dry rot). Bacterial soft rot is caused by Erwinia carotovora subsp. carotovora (syn. Pectobacterium carotovorum) and E. carotovora subsp. atroseptica (syn. Pectobacterium atrosepticum). In Wisconsin, E. carotovora subsp. carotovora causes the majority of losses (A. Charkowski, personal communication). $P$. infestans and $P$. erythroseptica are primary pathogens able to infect tubers directly, through the eyes or the periderm. Conversely, E. carotovora subsp. carotovora, E. carotovora subsp. atroseptica, Pythium ultimum, or F. sambucinum are generally associated with tuber tissues infected by primary pathogens,

Corresponding author: Z. K. Atallah; E-mail address: atila@plantpath.wisc.edu

DOI: 10.1094/PHYTO-96-1037

(c) 2006 The American Phytopathological Society physiologically stressed (e.g., periderm immaturity, bruising, and open lenticels) or damaged mechanically during harvest and handling $(15,23,26)$.

Infections with the above-mentioned pathogens occur in field and storage facilities, where management practices affect symptom development and storability of crops. Constant high relative humidity is required during potato storage to prevent tuber dehydration and weight loss, and ventilation air is frequently recirculated. Such conditions favor increases in pathogen populations, distribution of airborne inoculum, and infection of additional tubers. Tubers destined for processing (fries, chips, and dehydration, etc.) are routinely piled to heights of 5.5 to $7.5 \mathrm{~m}$ (18 to 20 feet) and maintained at approximately $95 \%$ relative humidity at 7 to $13^{\circ} \mathrm{C}\left(45\right.$ to $\left.55^{\circ} \mathrm{F}\right)$. Such conditions are favorable for sporulation and infection by pathogens that can penetrate tubers directly through the tuber lenticels, periderm, or eyes, or indirectly through wounds, to cause decay. Nevertheless, such storage conditions are required to preserve the marketing qualities of potato tubers (prolonged dormancy, processing qualities, minimal water loss, and minimal pressure bruising).

Tubers infected with any of the aforementioned pathogens could serve as inoculum sources for adjacent tubers during storage, leading to a rapid spread of disease. Anecdotal reports of collapsed piles and liquid running out storage doors can be a recurrent theme in years of excessive rainfall and elevated temperatures during harvest and the early storage period. Water condensation from tuber respiration and leakage from infected tubers serve as a medium for the spread and germination of all the above-mentioned pathogens.

Reliance on postharvest pesticides, such as hydrogen peroxide, chlorine dioxide, or ozone is frequent, even though such pesticides have not conclusively been shown to impact disease onset or reduce losses under controlled experimental conditions $(9,20,35)$. There is an urgent need to develop an alternative to the reliance 
on pesticides in potato storages with management recommendations that reduce storage losses and to develop storage-expectancy prediction models.

Quantification of pathogen levels prior to and during storage is expected to assist processors in key decisions related to storage options. Such specific information does not exist at this time and needs to be generated using methods that would allow the detection of the smallest possible number of propagules (conidia, sporangia, and oospores, etc.). Real-time quantitative-polymerase chain reaction (Q-PCR) allows for increased sensitivity and target quantification compared with conventional PCR (6,7,27,37-39). Ribosomal DNA (rDNA) sequences, especially the internally transcribed spacer region (ITS), have been repeatedly used as
PCR and Q-PCR primers to detect a number of different fungal pathogens in potato tissue $(6,7,16,24,32-34)$. High target copy numbers in fungal propagules allow for easy amplification and detection. However, the number of rDNA copies fluctuates with age and stage of growth of organisms (21). Furthermore, nonorthologous copies of the ITS region within one species and among strains in the same species are described in the literature (14). Such discrepancies may hamper accurate quantifications of propagule numbers in the starting material, and limit the ability to compare among samples. Conversely, single-copy genes could serve as specific primer sources that allow for constant pathogen quantification regardless of age and growth stage. Quantification of pathogen loads on potato tubers prior to storage

TABLE 1. List of fungi, oomycetes, and bacteria used to design and evaluate specific quantitative-polymerase chain reaction (Q-PCR) primers (threshold cycle $[\mathrm{Ct}]$ values of Q-PCR assay are also listed)

\begin{tabular}{|c|c|c|c|c|c|c|c|c|}
\hline \multirow[b]{2}{*}{ Organism } & \multirow[b]{2}{*}{ Origin } & \multirow[b]{2}{*}{ Source } & \multirow[b]{2}{*}{ Crop } & \multicolumn{5}{|c|}{$\mathrm{Ct}$ values with specific primers } \\
\hline & & & & $\begin{array}{l}\text { Phytophthora } \\
\text { infestans }\end{array}$ & $\begin{array}{l}\text { Pythium } \\
\text { ultimum }\end{array}$ & $\begin{array}{l}\text { Phytophthora } \\
\text { erythroseptica }\end{array}$ & $\begin{array}{l}\text { Fusarium } \\
\text { sambucinum }\end{array}$ & $\begin{array}{c}\text { Erwinia } \\
\text { carotovora }\end{array}$ \\
\hline Alternaria daucii PMR92 & Wisconsin & Rogers $^{\mathrm{a}}$ & Carrot & $\ldots$ & $\ldots$ & $\ldots$ & $\mathrm{NA}^{\mathrm{b}}$ & $\ldots$ \\
\hline Alternaria solani NR100 & Wisconsin & Rozensweig ${ }^{c}$ & Potato & $\ldots$ & $\ldots$ & $\ldots$ & NA & $\ldots$ \\
\hline Bipolaris maydis & Wisconsin & Nakhla $^{\mathrm{d}}$ & Corn & $\ldots$ & $\ldots$ & $\ldots$ & NA & $\ldots$ \\
\hline Colletotrichum coccodes & Wisconsin & Atallah & Potato & NA & NA & NA & NA & $\ldots$ \\
\hline Erwinia amylovora Ea246 & Illinois & Charkowski ${ }^{\mathrm{e}}$ & Raspberry & $\ldots$ & $\ldots$ & $\ldots$ & $\ldots$ & NA \\
\hline Erwinia amylovora Ea273 & New York & Charkowski & Apple & $\ldots$ & $\ldots$ & $\ldots$ & $\ldots$ & NA \\
\hline Erwinia carotovora atroseptica Ecc21 & Netherlands & Charkowski & Potato & NA & NA & NA & NA & 11.4 \\
\hline \multirow{2}{*}{ Erwinia carotovora atroseptica Eca6 } & British & & & & & & & \\
\hline & Columbia & Charkowski & Potato & & & & & 11.6 \\
\hline Erwinia carotovora beta-vascularum Ecb1 & California & Charkowski & Sugar beet & $\ldots$ & $\ldots$ & $\ldots$ & $\ldots$ & 29.2 \\
\hline Erwinia carotovora beta-vascularum Ecb2 & California & Charkowski & Sugar beet & $\ldots$ & $\ldots$ & $\ldots$ & $\ldots$ & 27.4 \\
\hline Erwinia carotovora carotovora WPP17 & Wisconsin & Charkowski & Potato & NA & NA & NA & NA & 24.5 \\
\hline Erwinia carotovora carotovora WPP14 & Wisconsin & Charkowski & Potato & $\ldots$ & $\ldots$ & $\ldots$ & $\ldots$ & 13.5 \\
\hline Erwinia carotovora wasabi SCRI 488 & Japan & Charkowski & Wasabi & $\ldots$ & $\ldots$ & $\ldots$ & $\ldots$ & 15.4 \\
\hline Erwinia chrysanthemi CUCPB1018 & Florida & Charkowski & Philodendron & $\ldots$ & $\ldots$ & $\ldots$ & $\ldots$ & NA \\
\hline Erwinia chrysanthemi CUCPB 1617 & California & Charkowski & Harrisia & NA & NA & NA & NA & NA \\
\hline Erwinia lupincola Elu W3L16 & Washington & Charkowski & Lupinus & $\ldots$ & $\ldots$ & $\ldots$ & $\ldots$ & NA \\
\hline Erwinia nigrifluens Eni 5D312 & - & Charkowski & - & $\ldots$ & $\ldots$ & $\ldots$ & $\ldots$ & NA \\
\hline Erwinia persicinus Epe $9108-82$ & Japan & Charkowski & Tomato & $\ldots$ & $\ldots$ & $\ldots$ & $\ldots$ & 24.9 \\
\hline Erwinia pyrifolia Ep 1/96 & South Korea & Charkowski & Pear & $\ldots$ & $\ldots$ & $\ldots$ & $\ldots$ & NA \\
\hline Erwinia quercina Equ 11D3 & - & Charkowski & - & $\ldots$ & $\ldots$ & $\ldots$ & $\ldots$ & NA \\
\hline Erwinia rhapontici Erh 739 & UK & Charkowski & Rhubarb & $\ldots$ & $\ldots$ & $\ldots$ & $\ldots$ & 25.8 \\
\hline Erwinia salicis Esa 15712 & UK & Charkowski & Willow & $\ldots$ & $\ldots$ & $\ldots$ & $\ldots$ & NA \\
\hline Erwinia amylovora Ea 246 & Illinois & Charkowski & Raspberry & $\ldots$ & $\ldots$ & $\ldots$ & $\ldots$ & NA \\
\hline Fusarium acuminatum NRRL 28654 & - & O’Donnell $^{\mathrm{f}}$ & - & $\ldots$ & $\ldots$ & $\ldots$ & 17.8 & $\ldots$ \\
\hline Fusarium avenaceum NRRL 25892 & - & O’Donnell & - & $\ldots$ & $\ldots$ & $\ldots$ & 16.6 & $\ldots$ \\
\hline Fusarium coeruleum NRRL 20434 & Wisconsin & O’Donnell & Potato & $\ldots$ & $\ldots$ & $\ldots$ & NA & $\ldots$ \\
\hline Fusarium culmorum NRRL 25475 & - & O’Donnell & - & $\ldots$ & $\ldots$ & $\ldots$ & 16.4 & $\ldots$ \\
\hline Fusarium eumartii NRRL 22397 & - & O’Donnell & - & $\ldots$ & $\ldots$ & $\ldots$ & NA & $\ldots$ \\
\hline Fusarium graminearum NRRL 34097 & - & O’Donnell & - & $\ldots$ & $\ldots$ & $\ldots$ & 19.2 & $\ldots$ \\
\hline Fusarium moniliforme A149 & California & Rouse ${ }^{2}$ & Corn & $\ldots$ & $\ldots$ & $\ldots$ & NA & $\ldots$ \\
\hline Fusarium oxysporum NRRL 25891 & - & O’Donnell & - & $\ldots$ & $\ldots$ & $\ldots$ & NA & $\ldots$ \\
\hline Fusarium oxysporum FO916 & California & Rouse & Barley grains & $\ldots$ & $\ldots$ & $\ldots$ & NA & $\ldots$ \\
\hline Fusarium oxysporum FO1055 & Wisconsin & Rouse & Carrot & $\ldots$ & $\ldots$ & $\ldots$ & NA & $\ldots$ \\
\hline Fusarium proliferatum D4853 & - & Rouse & - & $\ldots$ & $\ldots$ & $\ldots$ & NA & $\ldots$ \\
\hline Fusarium sambucinum Fsamb Med\#2 & Wisconsin & Atallah & Potato & NA & NA & NA & 16.5 & $\ldots$ \\
\hline Fusarium subglutinans B3852 & - & Rouse & - & $\ldots$ & $\ldots$ & $\ldots$ & NA & $\ldots$ \\
\hline Fusarium venenatum NRRL 22196 & - & O’Donnell & - & $\ldots$ & $\ldots$ & $\ldots$ & NA & $\ldots$ \\
\hline Fusarium ventricosum NRRL 22241 & - & O’Donnell & - & $\ldots$ & $\ldots$ & $\ldots$ & NA & $\ldots$ \\
\hline Phytophthora cactorum 327 & - & Tooley ${ }^{\mathrm{h}}$ & - & NA & NA & NA & $\ldots$ & $\ldots$ \\
\hline Phytophthora capsici & Wisconsin & Tooley & Pepper & NA & NA & NA & $\ldots$ & $\ldots$ \\
\hline \multirow[t]{2}{*}{ Phytophthora cryptogea 390} & - & Tooley & - & NA & NA & 17.4 & NA & NA \\
\hline & & & & & & & \multicolumn{2}{|c|}{ (Continued on next page) } \\
\hline
\end{tabular}

${ }^{\text {a }}$ P. M. Rogers, Department of Plant Pathology, University of Wisconsin-Madison.

b $\mathrm{NA}=$ no amplification.

${ }^{c}$ N. Rozensweig, Department of Plant Pathology, University of Wisconsin-Madison.

${ }^{\mathrm{d}}$ M. Nakhla, Department of Plant Pathology, University of Wisconsin-Madison.

e A. Charkowski, Department of Plant Pathology, University of Wisconsin-Madison.

${ }^{f}$ K. O'Donnell, USDA-ARS, NCAUR, Peoria, IL.

g D. Rouse, Department of Plant Pathology, University of Wisconsin-Madison.

${ }^{\text {h }}$ P. Tooley, USDA-ARS, NAA, FDWSRU, Fort Detrick, MD.

i J. Helgeson, Department of Plant Pathology, University of Wisconsin-Madison.

${ }^{j}$ F. Martin, USDA-ARS, PWA, Salinas, CA.

${ }^{k}$ G. Jung, Department of Plant Pathology, University of Wisconsin-Madison. 
would provide growers and storage managers with a decisionmaking tool regarding the destiny of crops. Crops with high pathogen loads (number of propagules carried by individual tubers) could be processed shortly after harvest, while those with lower pathogen loads could be stored for longer periods. Additionally, storage conditions could be optimized according to pathogen loads.

The objective of the current study was to design high efficiency Q-PCR primers to detect and quantify five major pathogens of potato tubers ( $P$. infestans, $P$. erythroseptica, Pythium ultimum, E. carotovora, and $F$. sambucinum) or closely related organisms associated with the disease. Such primer pairs are aimed at enabling the absolute quantification of minimal amounts of specific pathogens in the presence of high amounts of host DNA.

\section{MATERIALS AND METHODS}

Isolate collections. A collection of isolates of $P$. infestans, P. erythroseptica, Pythium ultimum, F. sambucinum, E. carotovora subsp. carotovora, and E. carotovora subsp. atroseptica representative of different genotypes (whenever available or identified) and various geographic locations was used to ensure a wide representation of the pathogen (Table 1). Also, collections of fungi, bacteria, and oomycetes associated with potato (tubers and aerial parts), rotational crops, as well as species within the same genus were used in the design and testing of primers.

Primer design. Sequences of functional protein coding genes were generated for the purpose of designing specific primers for P. infestans, P. erythroseptica, Pythium ultimum, F. sambucinum,

TABLE 1. (Continued from preceding page)

\begin{tabular}{|c|c|c|c|c|c|c|c|c|}
\hline \multirow[b]{2}{*}{ Organism } & \multirow[b]{2}{*}{ Origin } & \multirow[b]{2}{*}{ Source } & \multirow[b]{2}{*}{ Crop } & \multicolumn{5}{|c|}{$\mathrm{Ct}$ values with specific primers } \\
\hline & & & & $\begin{array}{l}\text { Phytophthora } \\
\text { infestans }\end{array}$ & $\begin{array}{l}\text { Pythium } \\
\text { ultimum }\end{array}$ & $\begin{array}{l}\text { Phytophthora } \\
\text { erythroseptica }\end{array}$ & $\begin{array}{c}\text { Fusarium } \\
\text { sambucinum }\end{array}$ & $\begin{array}{c}\text { Erwinia } \\
\text { carotovora }\end{array}$ \\
\hline Phytophthora drecshlerii 401 & - & Tooley & - & NA & NA & NA & $\ldots$ & $\ldots$ \\
\hline Phytophthora erythroseptica Pery Med\#2 & Wisconsin & Atallah & Potato & NA & NA & 19.6 & $\ldots$ & NA \\
\hline Phytophthora erythroseptica Pery Med\#4 & Wisconsin & Atallah & Potato & NA & NA & 19.9 & $\ldots$ & $\ldots$ \\
\hline Phytophthora erythroseptica Pery 347 & Wisconsin & Atallah & Potato & $\ldots$ & $\ldots$ & 20.1 & $\ldots$ & $\ldots$ \\
\hline Phytophthora erythroseptica Pery & Wisconsin & Atallah & Potato & $\ldots$ & $\ldots$ & 18.5 & $\ldots$ & $\ldots$ \\
\hline Phytophthora erythroseptica Pery ID & Idaho & Atallah & Potato & $\ldots$ & $\ldots$ & 21.2 & $\ldots$ & $\ldots$ \\
\hline Phytophthora fragariae 398 & - & Tooley & - & NA & NA & NA & $\ldots$ & $\ldots$ \\
\hline Phytophthora illicis 344 & - & Tooley & - & NA & NA & NA & $\ldots$ & $\ldots$ \\
\hline Phytophthora infestans US-1 US 940501 & - & Helgeson $^{\mathrm{i}}$ & Potato & 20.9 & $\ldots$ & $\ldots$ & $\ldots$ & $\ldots$ \\
\hline Phytophthora infestans US-6 BIN-16 & New York & Helgeson & Potato & 19.6 & $\ldots$ & $\ldots$ & $\ldots$ & $\ldots$ \\
\hline Phytophthora infestans US-7 BG-8 & New York & Helgeson & Potato & 19.9 & $\ldots$ & $\ldots$ & $\ldots$ & $\ldots$ \\
\hline Phytophthora infestans US-8 US 940480 & - & Helgeson & Potato & 21.1 & NA & NA & NA & NA \\
\hline Phytophthora infestans US-8 126-C-18 & North Dakota & Helgeson & Potato & 24 & $\ldots$ & $\ldots$ & $\ldots$ & $\ldots$ \\
\hline Phytophthora infestans US-8 693-3 & North Dakota & Helgeson & Potato & 23.2 & $\ldots$ & $\ldots$ & $\ldots$ & $\ldots$ \\
\hline Phytophthora megasperma 437 & - & Tooley & - & NA & NA & NA & $\ldots$ & $\ldots$ \\
\hline Phytophthora mirabilis 340 & - & Tooley & - & 17.9 & NA & NA & $\ldots$ & $\ldots$ \\
\hline Phytophthora nicotiana 361 & - & Tooley & - & NA & $\ldots$ & $\ldots$ & $\ldots$ & $\ldots$ \\
\hline Phytophthora palmivora 327 & - & Tooley & - & NA & NA & NA & $\ldots$ & $\ldots$ \\
\hline Phytophthora phaseoli 404 & - & Tooley & - & 19.7 & NA & NA & $\ldots$ & $\ldots$ \\
\hline Phytophthora sojae & Wisconsin & Nakhla & Soybean & NA & NA & NA & $\ldots$ & $\ldots$ \\
\hline Pythium aphanidermatum 1987-60 & New York & Martin $^{\mathrm{j}}$ & - & NA & NA & NA & $\ldots$ & $\ldots$ \\
\hline Pythium arrhenomanes 1994-15 & New York & Martin & - & NA & NA & NA & $\ldots$ & $\ldots$ \\
\hline Pythium catenulatum 1986-8 & India & Martin & - & NA & NA & NA & $\ldots$ & $\ldots$ \\
\hline Pythium insidiosum 58643 & - & Martin & - & NA & NA & NA & $\ldots$ & $\ldots$ \\
\hline Pythium irregulare 1987-68 & Washington & Martin & - & NA & NA & NA & $\ldots$ & $\ldots$ \\
\hline Pythium sylvaticum $1987-14$ & Iowa & Martin & - & NA & NA & NA & $\ldots$ & $\ldots$ \\
\hline Pythium torulosum 1991-19 & Ohio & Martin & - & NA & NA & NA & $\ldots$ & $\ldots$ \\
\hline Pythium ultimum PultMed\#1 & Wisconsin & Atallah & Potato & NA & 17.2 & NA & NA & NA \\
\hline Pythium ultimum PultMed\#2 & Wisconsin & Atallah & Potato & NA & 20.3 & NA & $\ldots$ & $\ldots$ \\
\hline Pythium ultimum 1987-65 & Florida & Martin & - & NA & 16.5 & NA & $\ldots$ & $\ldots$ \\
\hline Pythium ultimum 1987-69 & New York & Martin & - & NA & 19.1 & $\ldots$ & $\ldots$ & $\ldots$ \\
\hline Pythium ultimum 1991-20 & Hawaii & Martin & - & NA & 18.6 & $\ldots$ & $\ldots$ & $\ldots$ \\
\hline Pythium ultimum 58-1 & Florida & Martin & - & NA & 16.7 & $\ldots$ & $\ldots$ & $\ldots$ \\
\hline Pythium ultimum HS 26-1 & New Mexico & Martin & - & NA & 19.4 & NA & $\ldots$ & $\ldots$ \\
\hline Pythium ultimum HS 23-1 & Arizona & Martin & - & NA & 18.9 & $\ldots$ & $\ldots$ & $\ldots$ \\
\hline Pythium ultimum v. spor $1993-25$ & Maryland & Martin & - & NA & 20.2 & NA & $\ldots$ & $\ldots$ \\
\hline Pythium ultimum v. spor $1993-26$ & Lebanon & Martin & - & NA & 17.8 & $\ldots$ & $\ldots$ & $\ldots$ \\
\hline Pythium volutum $1995-105$ & Japan & Martin & - & NA & NA & NA & $\ldots$ & $\ldots$ \\
\hline Rhizoctonia solani & Wisconsin & Atallah & Potato & $\ldots$ & $\ldots$ & $\ldots$ & NA & $\ldots$ \\
\hline Sclerotinia homeocarpa & Wisconsin & Jungk & Turfgrass & $\ldots$ & $\ldots$ & $\ldots$ & NA & $\cdots$ \\
\hline Sclerotinia sclerotiorum & Wisconsin & Atallah & Bean & $\ldots$ & $\ldots$ & $\ldots$ & NA & $\ldots$ \\
\hline Streptomyces scabies & Wisconsin & Atallah & Potato & NA & NA & NA & NA & NA \\
\hline Streptomyces scabies & Wisconsin & Atallah & Potato & NA & NA & NA & NA & NA \\
\hline Verticillium albo-atrum DV20 & Wisconsin & Rouse & Potato & NA & NA & NA & NA & NA \\
\hline Verticillium albo-atrum LV79 & Wisconsin & Rouse & Alfalfa & $\ldots$ & $\ldots$ & $\ldots$ & NA & $\ldots$ \\
\hline Verticillium chlamydosporium NRRL 13093 & - & Rouse & - & $\ldots$ & $\ldots$ & $\ldots$ & NA & $\ldots$ \\
\hline Verticillium cinnebarinum NRRL A-3665 & - & Rouse & - & $\ldots$ & $\ldots$ & $\ldots$ & NA & $\ldots$ \\
\hline Verticillium dahliae V18 & Wisconsin & Rouse & Potato & NA & NA & NA & NA & NA \\
\hline Verticillium dahliae LV75 & Oregon & Rouse & Potato & $\ldots$ & $\ldots$ & $\ldots$ & NA & $\ldots$ \\
\hline Verticillium lateritium NRRL A-18693 & - & Rouse & - & $\ldots$ & $\ldots$ & $\ldots$ & NA & $\ldots$ \\
\hline Verticillium lecanii NRRL A-18240 & - & Rouse & - & $\ldots$ & $\ldots$ & $\ldots$ & NA & $\ldots$ \\
\hline Verticillium nigriscens Nigriscens & - & Rouse & - & $\ldots$ & $\ldots$ & $\ldots$ & NA & $\ldots$ \\
\hline Verticillium psaleotae NRRL A-18376 & - & Rouse & - & $\ldots$ & $\ldots$ & $\cdots$ & NA & $\ldots$ \\
\hline Verticillium tricorpus NRRL 13690 & - & Rouse & - & $\ldots$ & $\ldots$ & $\ldots$ & NA & $\ldots$ \\
\hline
\end{tabular}


and E. carotovora subsp. carotovora, and subsp. atroseptica by application of sequence comparative analyses. For this purpose, seven universal primer pairs were used: $r p b l$ (ribosomal polymerase B1) (29), efl $\alpha$ (elongation factor $1 \alpha$ ), cal (calmodulin), act (actin), ras (RAS protein) (2), $\beta$-tubulin, and H3 (histone 3 ) $(11,13)$. These sequences are typically highly conserved within species, but potentially polymorphic among species and genera. $R p b 1$ primers failed to amplify fungal DNA, and their use was restricted to oomycetes. Sequences of the $m p d$ gene (mannitol- $p$ dehydrogenase) for various species of the bacterial genus Erwinia were obtained from M. Hibbing (UW-Madison, School of Veterinary Medicine). All primer pairs designed in this study are highlighted in Table 2, and represent an excerpt of the total number of primer pairs designed from the various gene sequences obtained. Nonspecific primer pairs or regions exhibiting no polymorphisms among the amplified organisms are not listed in Table 2.

PCR amplifications were conducted in a Bio-Rad iCycler thermocycler (Bio-Rad, Hercules, CA), one half degree lower than the calculated melting temperature for the primers to maximize amplification specificity as predicted by Primer3 (25). The 20- $\mu \mathrm{l}$ amplification reactions included $1 \mathrm{ng}$ of total purified culture DNA and $200 \mathrm{nM}$ of each primer in PCR Master Mix (Promega, Madison, WI; $1.5 \mathrm{mM} \mathrm{MgCl}_{2}, 200 \mathrm{nM}$ of each dNTP, and 25 units of $\mathrm{Taq}$ polymerase per $\mathrm{ml}$ ). Amplification products were visualized in $0.8 \%$ agarose gels. Both DNA strands of products smaller than $700 \mathrm{bp}$ were sequenced directly following PCR amplification without cloning. PCR-amplified products were cleaned using AMPure magnetic beads (Agencourt, Beverly, MA) prior to labeling with ABI BigDye Terminator version 3.1 (Applied Biosystems, Foster City, CA), and excess labeling dye was removed with CleanSEQ magnetic beads (Agencourt). Amplification products in excess of $700 \mathrm{bp}$ were cloned prior to sequencing (in both directions) in the Topo TA Cloning Kit (Invitrogen, Carlsbad, CA). Sequencing was performed at the University of Wisconsin Biotechnology Center with the ABI $3730 \times 1$ DNA Analyzer (Applied Biosystems). Sequences were visualized in Chromas (Technelysium, Southport, Queensland, Australia), aligned in Clustal W $(30,31)$, and the consensus sequence was edited in BioEdit (12).

Sequences from the target organisms, related species, genera, and other pathogens of potato and rotational crops were aligned in Clustal W. Primers were designed from areas polymorphic among closely related species, yet monomorphic within the target species. Prospective primer sequences were evaluated using Primer3 for potential self-compatibility melt temperatures and GC clamping. Subsequently, candidate primers and amplicons were evaluated in Mfold (40) for potential secondary structures, which would reduce amplification efficiency. All Q-PCR products were designed not to exceed $150 \mathrm{bp}$ in size. A primer pair was also designed to amplify the act gene (actin) in potato (GenBank accession no. $\mathrm{X} 55751$ ) to be used as an internal control.

Evaluation of primer specificity. Primer specificity was tested against the DNA collection described previously. Q-PCR amplifications were conducted in triplicates, in a Bio-Rad iCycler iQ real-time PCR system using the iQ Supermix SYBR-Green (Bio-Rad) with $\approx 1 \mathrm{ng}$ of DNA and $200 \mathrm{mM}$ of each primer in 20$\mu$ total volume. The following amplification protocol was used: initial denaturation of $3 \mathrm{~min}$ at $95^{\circ} \mathrm{C}$ followed by 40 cycles of $95^{\circ} \mathrm{C}$ for $10 \mathrm{~s}$ and $62.1^{\circ} \mathrm{C}$ (identified following temperature gradient amplifications) for $35 \mathrm{~s}$. Melt curve analysis was used to distinguish potential primer dimers and nonspecific amplification products.

Primer efficiency. Amplification efficiency (efficiency $=$ $\left.10^{(-1 / \text { slope })}-1\right)$ of all primer pairs was tested on a fivefold serial dilution of the target pathogen DNA, and a sixfold serial dilution of potato tuber DNA for the potato control primers. Amplifications of pathogen DNA targets were performed in the presence and absence of potato DNA. Twenty-five nanograms of potato DNA extracted from a disease-free and surface-disinfested tuber was added to the serial dilution of pathogen DNA. Q-PCR efficiencies were calculated using the Bio-Rad iCycler version 3.1 software. To determine the potential impact of the addition of potato DNA on the amplification of the target DNA, mean threshold cycle $(\mathrm{Ct})$ values generated in the presence and absence of potato DNA were compared using Fisher's $t$ tests (PROC $t$ test in SAS [SAS Institute, Cary, NC]) for each of the primer pairs. Additionally, the slopes of the efficiency equations were compared in an analysis of covariance (ANCOVA) for each primer pair. Equations with similar slopes result in $F$ statistics greater than one, indicating that variability is greater within an equation compared with between equations (3).

Tuber inoculation. Russet Burbank tubers (170 to $285 \mathrm{~g}$ [6 to $10 \mathrm{oz}]$.$) that were specifically planted for this study in fumigated$ field plots, never exposed to fungicides and not showing any disease symptoms, were surface-disinfested (10 $\mathrm{min}$ in $10 \%$ bleach) and then inoculated with zoospores of $P$. infestans or $P$. erythroseptica. Inoculations were performed using $1 \times 10^{4}$ zoospores per $\mathrm{ml}$ for $P$. erythroseptica (isolate Pery347) and zoospores from sporangial suspensions adjusted to $1 \times 10^{4}$ sporangia per $\mathrm{ml}$ for $P$. infestans (US 940480, genotype US-8). The number of zoospores generated by the sporangial suspension of $P$. infestans was not quantified (average of eight zoospores per sporangium). Sporangia of $P$. infestans produced on inoculated tuber disks following Porter and Johnson (22) were washed off with autoclaved water, and their concentration was estimated with a hemacytometer and subsequently adjusted to $1 \times 10^{4}$ sporangia per $\mathrm{ml}$. Sporangia of $P$. erythroseptica were produced following Mitchell et al. (19), which includes the use of V8 broth and soil extract. Sporangial suspensions of both $P$. infestans and P. ery-

TABLE 2. Primers developed to detect and quantify five potato pathogens and the potato act gene (actin) ${ }^{\mathrm{a}}$

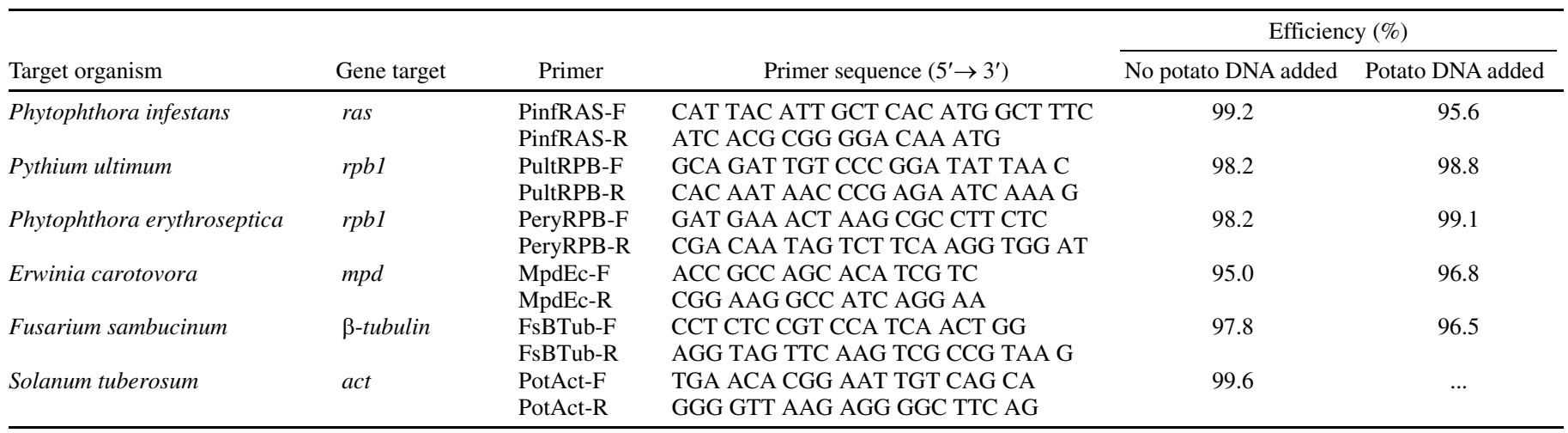

\footnotetext{
a Examples of primer efficiencies are listed, in the presence and absence of the host DNA. Primer efficiencies were calculated in the Bio-Rad iCycler software in
} accordance with the formula $\mathrm{E}=\left(10^{(-1 / \mathrm{slope})}-1\right) \times 100$. 
throseptica were placed at $4^{\circ} \mathrm{C}$ for $2 \mathrm{~h}$ to release zoospores, and kept on ice during the inoculation of tubers.

A 50- $\mu$ l aliquot from each of the inoculum suspensions was placed on a $1 \mathrm{~cm}^{2}$ piece of filter paper and inverted onto an eye on the apical part of tubers. Tubers inoculated with $P$. infestans were placed in a dew chamber at $20^{\circ} \mathrm{C}$ in the dark for 4 days. Tubers inoculated with $P$. erythroseptica were subjected to a continuous mist at $20^{\circ} \mathrm{C}$ in the dark for $8 \mathrm{~h}$, and then incubated in the dark at $20^{\circ} \mathrm{C}$ for 4 days, with intermittent misting ( $15 \mathrm{~min}$ every hour).

Twelve cv. Russet Burbank tubers were inoculated with Pythium ultimum (isolate Pult Med\#2), 12 tubers were inoculated with $F$. sambucinum (isolate Fsamb Med), and 10 tubers were inoculated with E. carotovora subsp. carotovora (isolate WPP14). Surface-disinfested tubers were wounded in four locations along a longitudinal transect with a four-screw hole-puncher (hole diameter 0.5 and $0.2 \mathrm{~cm}$ deep). A circular plug of PAR (PCNBampicillin-rifampicin) culture medium (18) colonized by Pythium ultimum (diameter $0.5 \mathrm{~cm}$ ) and obtained from the edge of a growing colony was inserted into each wound. Tubers were inoculated with E. carotovora $\left(1 \times 10^{6} \mathrm{CFU} / \mathrm{ml}\right)$ and $F$. sambucinum $\left(1 \times 10^{4}\right.$ conidia per $\left.\mathrm{ml}\right)$ by placing a drop of inoculum suspension in each wound. The inoculum for the latter inoculations was obtained by washing actively growing cultures of $E$. carotovora and F. sambucinum with sterile water. The quantification of $F$. sambucinum conidia was performed with a hemacytometer, whereas a spectrophotometer was used to estimate the concentration of E. carotovora CFU. Inoculated tubers were placed for 4 days in a dark dew chamber at $15^{\circ} \mathrm{C}$. Controls consisted of two noninoculated tubers that were subjected to the same treatments as inoculated tubers, except that the inoculum was substituted with sterile water, or a sterile noncolonized agar plug in the case of Pythium ultimum.

DNA extractions from inoculated tubers. Inoculated tubers were disinfested (10 min in $10 \%$ bleach) after incubation to eliminate any pathogen propagules remaining on the surface. Juice from the inoculated tubers was extracted with an Acme Juicerator device (Waring Products, New Hartford, CT). A volume of $40 \mathrm{ml}$ of the juice was collected from each tuber into 50-ml conical tubes, and $4 \mathrm{~g}$ of polyvinylpyrrolidone (Fisher Scientific, Pittsburgh, PA) was added to each tube as a phenol binding agent and shaken vigorously. Tubes were centrifuged at $11,000 \times g$ for 15 min to precipitate eukaryotic and prokaryotic cells. The supernatant was discarded and DNA was extracted from $0.1 \mathrm{~g}$ of pelleted cells. DNA was extracted with the FastDNA Kit (QBiogene, Irvine, CA) following the manufacturer's recommendations. Subsequently, DNA extracts were subjected to cleanup using the AMPure magnetic beads to eliminate remaining potential PCR inhibitors. All DNA samples were quantified fluorometrically with Quant-iT PicoGreen dsDNA (Invitrogen) and stored at $4^{\circ} \mathrm{C}$ until used.

Q-PCR on inoculated tubers. One hundred picograms of total DNA (tuber plus pathogen DNAs) was subjected to Q-PCR amplifications with the same conditions described previously. Each DNA sample (i.e., individual tuber) was amplified in triplicate Q-PCRs.

To test for the absence of PCR inhibitors, each sample was spiked with $100 \mathrm{pg}$ of pure culture DNA of the pathogen under study. Pure culture DNA alone constituted the positive control, and no-template water samples constituted the negative controls. Any statistically significant increase in $\mathrm{Ct}$ value between positive control samples and spiked samples indicates a decreased efficiency of the amplification, attributable to PCR inhibitors. Additionally, the potato act gene in each sample was amplified using PotAct-F/PotAct-R as internal control.

Field samples. Tubers of cv. Gold Rush exhibiting symptoms of pink rot, leak, and soft rot were retrieved from a commercial storage facility in Almond, WI. No late blight epidemics have occurred in Wisconsin since 2002; hence, no naturally infected tubers could be found in the state. Disease symptoms were diagnosed visually and DNA was extracted from eight tubers showing definitive disease symptoms of each of the pathogens (24 tubers total). DNA extractions were completed using FastDNA on $0.2 \mathrm{~g}$ of tissues contiguous to disease lesions, and further purified using AMPure, as previously described. DNA was quantified fluorometrically and $1 \mathrm{ng}$ of total DNA was amplified using the primer pairs PeryRPB-F/PeryRPB-R, PultRPB-F/PultRPB-R, and MpdEc-F/MpdEc-R to detect and quantify $P$. erythroseptica, Pythium ultimum, and E. carotovora, respectively (Table 2). An equal DNA amount (1 ng total DNA) was used to quantify the potato host using primers PotAct-F/PotAct-R. In the absence of $P$. infestans from the tested samples, $2 \mathrm{pg}$ of $P$. infestans DNA (control) was added to all 24 tested samples to ensure the absence of PCR inhibitors. Primers PinfRAS-F/PinfRAS-R were used in Q-PCR amplifications. Substantial increases in $\mathrm{Ct}$ value from the $P$. infestans control indicate the presence of PCR inhibitor. All QPCR amplifications were carried out in triplicate using $20-\mu \mathrm{l}$ reaction volumes as previously described. $\Delta \mathrm{Ct}\left(\Delta \mathrm{Ct}=\mathrm{Ct}_{\mathrm{sample}}-\right.$ $\mathrm{Ct}_{\text {control }}$ ) was computed (10) based on the mean $\mathrm{Ct}$ values obtained. In all amplifications, DNA from pure cultures of each of the three pathogens was used as the positive control and notemplate water sample as the negative control. The infection coefficient (IC), which is the ratio of $\mathrm{Ct}_{\text {host }} / \mathrm{Ct}_{\text {pathogen }}$ (36), was computed for each sample tested.

\section{RESULTS}

Primer design. The generated primer pairs were amplified the following target genes: ras in $P$. infestans, rpbl in P. erythroseptica and Pythium ultimum, mpd in E. carotovora subsp. carotovora and subsp. atroseptica, $\beta$-tubulin in $F$. sambucinum, and act in potato (Table 2). Only primer pairs exhibiting minimal selfcompatibility and secondary structures and amplifying at similar annealing temperatures $\left(62\right.$ to $\left.63^{\circ} \mathrm{C}\right)$ were retained.

Primer specificity. The selected primer pairs amplified all isolates of the target species collected from various geographic locations, or belonging to different genotypes (Table 1). Nevertheless, two primer pairs ( $P$. infestans and E. carotovora) also amplified DNA fragments from close relatives not associated with potato. The primer pair targeting $P$. infestans (PinfRAS-F/ PinfRAS-R) also amplified DNA fragments from the phylogenetically related species $P$. mirabilis and $P$. phaseoli. The primer pair designed to amplify E. carotovora subsp. carotovora and subsp. atroseptica (MpdEc-F/MpdEc-R) also amplified fragments from subsp. wasabi and subsp. beta-vascularum, E. nigrifluens, and E. quercina. Melt curve analyses and DNA sequencing of the amplified product failed to differentiate between the intended target organisms and closely related ones amplified with the described primer pairs.

Primer pairs for $P$. erythroseptica (PeryRPB-F/PeryRPB-R) and F. sambucinum (FsBTub-F/FsBTub-R) were designed to detect close relatives associated with the same disease symptoms on potato. The primer pair targeting $P$. erythroseptica also detected $P$. cryptogea, described to cause pink rot symptoms in certain potato production areas. The primer pair targeting $F$. sambucinum amplified DNA fragments from $F$. avenaceum, $F$. culmorum, $F$. graminearum, and $F$. acuminatum, all associated with potato dry rot. The primer pair designed to amplify the actin gene in potato (PotAct-F/PotAct-R) did not amplify the DNA of 15 different pathogens commonly associated with potato (data not shown).

Primer efficiency. All six primer pairs exhibited primer efficiencies greater than or equal to $95 \%$ in the presence or absence of potato DNA (Table 2; Fig. 1). Ct values from the amplification of fivefold serial DNA dilutions of the five pathogens were not significantly different $(P>0.05)$ when $25 \mathrm{ng}$ of potato DNA was added (Table 3; Fig. 1). Furthermore, we found no significant differences in the ANCOVA on the slopes of the equations 
generated with each primer pair (Fig. 1). The primer pair PotActF/PotAct-R showed amplification efficiency greater than $99 \%$ over 6 orders of magnitude (Fig. 1).

Tuber inoculations. All tubers inoculated with $P$. erythroseptica and E. carotovora subsp. carotovora exhibited minor pink rot and soft rot lesions, respectively, 4 days postinoculation. Conversely, and because of the short incubation period, tubers inoculated with $P$. infestans, Pythium ultimum, or $F$. sambucinum did not show symptoms of late blight, leak, or dry rot, respectively. Moreover, a subset of tubers inoculated with $P$. infestans, Pythium ultimum, and $F$. sambucinum were incubated until the appearance of late blight, leak, and dry rot symptoms, respectively. In all instances, noninoculated control tubers did not show disease symptoms.

Q-PCR on inoculated tuber DNA. All five target pathogens were detected in $100 \mathrm{pg}$ of total DNA from all respective inoculated tubers, except for one tuber inoculated with $F$. sambucinum. No pathogen DNA target was amplified from noninoculated tubers (Table 4). Furthermore, $\mathrm{Ct}$ values were not statistically different between the DNA replicates $(P>0.05)$. No significant PCR inhibition was observed and no significant deviation in $\mathrm{Ct}$ values were observed between the positive controls and the posi- tive control-spiked samples. The potato act gene was amplified in all samples.

Field samples. All but one field sample tested positive for the targeted pathogen. Pythium ultimum and E. carotovora were detected in all eight symptomatic samples tested, respectively, while only seven samples tested positive for $P$. erythroseptica (Table 5). All negative controls failed to amplify any target DNA. $\Delta \mathrm{Ct}$ values varied between -1.5 and 1.1 for $P$. infestans-spiked samples, indicating minimal to no PCR inhibition. Infection coefficients varied between 0.7 and 1.1 .

\section{DISCUSSION}

We have developed a Q-PCR methodology for the detection and quantification of five pathogens of stored potato tubers. Currently, decisions by potato storage managers and processors regarding which harvested crops to store and the projected duration of storage are made solely on the basis of field and grower histories and visual observation of tubers at harvest. The intent of this study is to provide a method to develop a decision-making tool for the storage of potato crops sensitive to minute amounts of pathogen DNA associated with tubers (incidence of pathogen), as
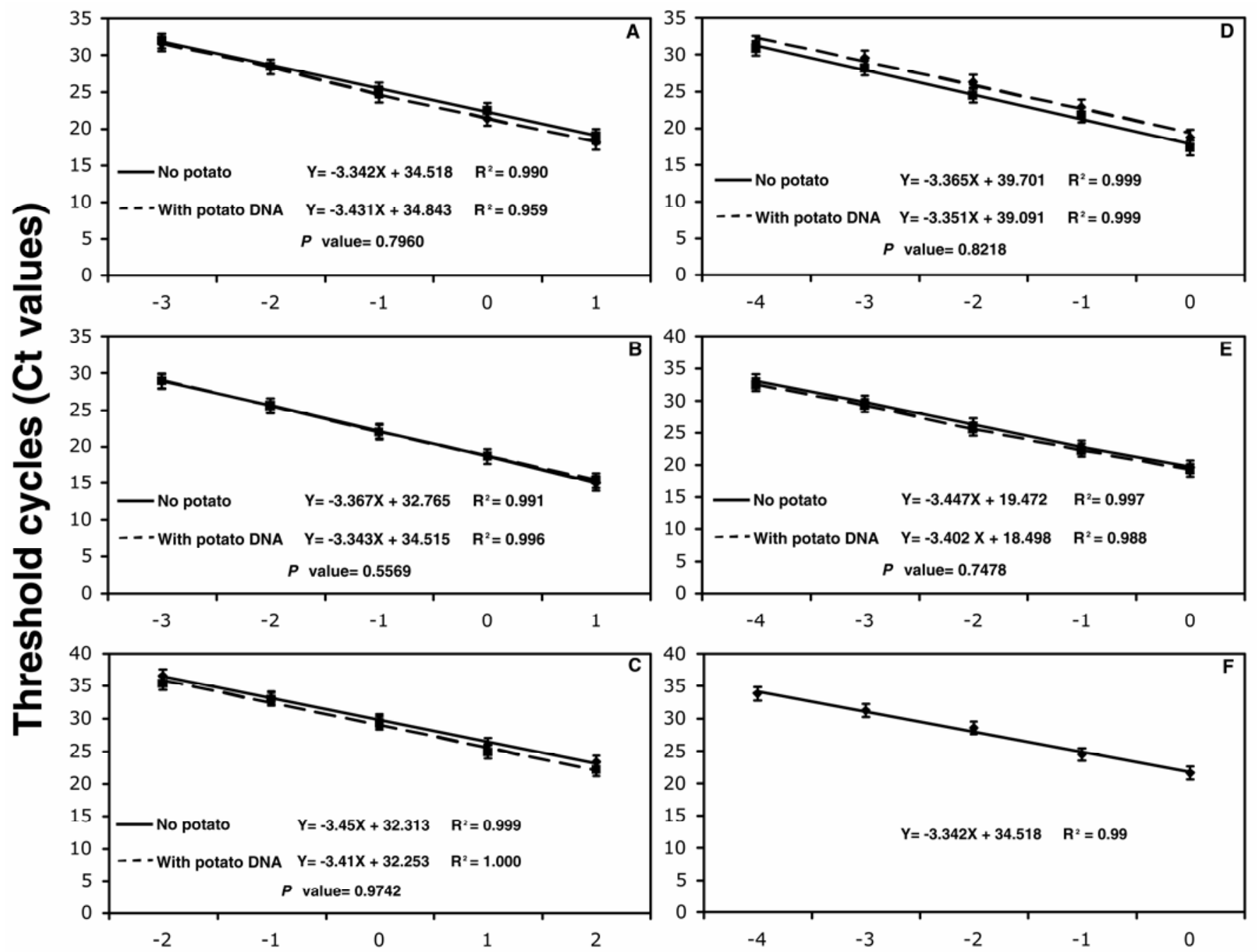

Target DNA amount $\left(\log _{10} n g\right)$

Fig. 1. Standard curves showing amplifications using the primer pairs A, PinfRAS for Phytophthora infestans, B, PeryRPB for Phytophthora erythroseptica, C, FsBtub for Fusarium sambucinum, D, PultRPB for Pythium ultimum, E, MpdEc for Erwinia carotovora subsp. carotovora, and F, PotAct for Solanum tuberosum. DNA from pure cultures of each pathogen and DNA from potato tuber was diluted over 5 orders of magnitude and amplified with or without the presence of host DNA (25 ng). Efficiency curve equations and correlation coefficients $\left(R^{2}\right)$ are included. $P$ values of analyses of covariance were used to compare equation slopes, but no significant differences were found in any primer pair. 
well as a quantification of that DNA (pathogen load). This measurement of the pathogen load could be used to apply different storage management strategies, to avoid disease, or reduce losses.

The six primer pairs designed in this study selectively amplified their intended DNA targets (Table 1). All primer pairs amplified DNA from multiple isolates of the intended species, from various geographic locations, or belonging to different genotypes. It is worth noting that because of the lack of sequence polymorphisms, the primer pair PinfRAS-F/PinfRAS-R targeting $P$. infestans also amplifies DNA fragments from $P$. mirabilis and $P$. phaseoli. These two oomycetes are not pathogens of potato (8) but are taxonomically closely related to $P$. infestans $(4,5,17)$. Furthermore, melt curve analyses and DNA sequencing of the products amplified from $P$. mirabilis and $P$. phaseoli failed to differentiate between those species and $P$. infestans (data not shown). Amplification of $P$. mirabilis or $P$. phaseoli, with primers designed to detect $P$. infestans, was reported in a number of other published studies $(24,33,34)$. Knowing that the likelihood of finding the DNA of $P$. mirabilis and $P$. phaseoli associated with potato is negligible, the primer pair is considered to be specific to $P$. infestans for this application. The primer pair PeryRPB-F/PeryRPB-R targeting $P$. erythroseptica was purposely designed to also detect $P$. cryptogea, which is associated with pink rot in some potato production regions (15). Similarly, the primer pair FsBTub-F/FsBTub-R targeting $F$. sambucinum was specifically designed to also amplify $F$. avenaceum, $F$. culmorum, $F$. graminearum, and $F$. acuminatum, all reported to cause dry rot in potatoes (28). The primer pair FsBTub-F/FsBTub-R does not amplify $F$. coeruleum, which causes decay of potato seed pieces in fields and is usually not associated with tuber decay in storage. Minimal sequence differences among the various subspecies of E. carotovora lead to a primer pair, MpdEc-F/MpdEc-R, which amplifies subsp. wasabi and subsp. betavascularum, in addition to the target soft-rotting subsp. carotovora and subsp. atroseptica. E. carotovora subsp. wasabi and subsp. betavascularum are not commonly found on potato. Another two species not associated with disease on potato, E. nigrifluens and E. quercina, were amplified. Encountering the DNA of the latter two species associated with potato DNA is highly unlikely; hence, making the primer pair MpdEc-F/MpdEc-R reasonably specific for the detection and quantification of soft rotting bacteria in/on potato.

Primer efficiencies were consistently between 95 and $100 \%$ over 5 orders of magnitude of target DNA concentration (Table 3; Fig. 1). Primer efficiencies remained high in the presence of high amounts of potato DNA in Q-PCRs, and no statistically significant differences were observed between slopes or among $\mathrm{Ct}$ values regardless of the presence or absence of potato DNA (Table 3; Fig. 1). In this study, we amplified as low as $0.5 \mathrm{pg}$ of Pythium ultimum DNA, $0.7 \mathrm{pg}$ of $P$. erythroseptica DNA, $1.1 \mathrm{pg}$ of $P$. infestans DNA, $7.5 \mathrm{pg}$ of $F$. sambucinum DNA, and $10 \mathrm{pg}$ of $E$. carotovora DNA (Table 3; Fig. 1). Additionally, we were able to consistently amplify $0.5 \mathrm{pg}$ of potato DNA (Table 3; Fig. 1), which we used to compute the infection coefficient values of field-collected and infected tubers. Amplifications of smaller concentrations were possible, but the variability among replicates became large. Such variation is common when dealing with minute amounts of DNA, where small differences are amplified exponentially (36).

Pathogens were successfully detected and amplified from fieldcollected potato tubers infected with $P$. erythroseptica, Pythium ultimum, and E. carotovora (Table 5). Confirmation of the presence of the pathogen was successful in eight samples tested for Pythium ultimum, eight tubers tested for E. carotovora, but only seven out of eight tubers tested for $P$. erythroseptica. Samples used to extract DNA were taken from an area contiguous to the observed lesions and not showing leak, soft rot, or pink rot symptoms, respectively. It is possible that the excised specimen in the negative assay was taken from an area that the pathogen had failed to colonize at the time of sampling.

We tested several methods to homogenize the potato periderm, but no blender or mixer provided a complete maceration/homogenization in a reasonable amount of time, or number of steps needed. Moreover, sonication failed to dislodge pathogen propagules and/or DNA from potato tissues. We found tuber juicing to be an adequate method to generate a homogenous sample from individual tubers.

The designed primers exhibited high sensitivity to low amounts of pathogen DNA. All described pathogen detections and quantifications were performed using $100 \mathrm{pg}$ of total DNA extracted a few days after tuber inoculation, in the presence or absence of symptoms. Additionally, we were able to detect $P$. erythroseptica, Pythium ultimum, and E. carotovora from $1 \mathrm{ng}$ of DNA extracted from field-collected tubers showing symptoms of pink rot, leak, and soft rot, respectively. Sensitivity to very low amounts of target DNA is essential to detect small numbers of pathogen propagules, especially in commercial situations where low pathogen incidence and low pathogen loads can potentially lead to substantial economic losses. This study is a first step in a methodology to provide processors and storage managers with the means to identify and quantify potential threats with accuracy.

TABLE 3. Five-point serial dilutions of Phytophthora infestans, Phytophthora erythroseptica, Pythium ultimum, Fusarium sambucinum, Erwinia carotovora subsp. carotovora DNA from pure cultures, and a six-point serial Solanum tuberosum (cv. Russet Burbank) tuber DNA

\begin{tabular}{|c|c|c|c|c|}
\hline \multirow[b]{2}{*}{ Organism (isolate) } & \multirow{2}{*}{$\begin{array}{l}\text { Primer } \\
\text { pair }\end{array}$} & \multirow{2}{*}{$\begin{array}{c}\text { DNA } \\
\text { amount (ng) }\end{array}$} & \multicolumn{2}{|c|}{$\begin{array}{c}\text { Potato DNA } \\
\text { added }(\mathrm{Ct} \\
\text { values })^{\mathrm{a}}\end{array}$} \\
\hline & & & No & Yes \\
\hline P. infestans (US-8) & PinfRAS & $\begin{array}{l}1.10 \mathrm{E}-03 \\
1.10 \mathrm{E}-02 \\
1.10 \mathrm{E}-01 \\
1.1 \\
11\end{array}$ & $\begin{array}{l}31.5 \\
28.3 \\
24.5 \\
21.3 \\
18.1 \\
t \text { test }\end{array}$ & $\begin{array}{c}31.9 \\
28.4 \\
25.2 \\
22.4 \\
18.9 \\
0.83\end{array}$ \\
\hline P. erythroseptica (Pery 347$)$ & PeryRPB & $\begin{array}{l}7.00 \mathrm{E}-04 \\
7.00 \mathrm{E}-03 \\
7.00 \mathrm{E}-02 \\
7.00 \mathrm{E}-01 \\
7\end{array}$ & $\begin{array}{l}31.5 \\
29.5 \\
26.2 \\
22.8 \\
18.7 \\
t \text { test }\end{array}$ & $\begin{array}{c}30.8 \\
28.1 \\
24.4 \\
21.7 \\
17.3 \\
0.96\end{array}$ \\
\hline F. sambucinum (Fsamb Med) & FsBTub & $\begin{array}{l}7.50 \mathrm{E}-03 \\
7.50 \mathrm{E}-02 \\
7.50 \mathrm{E}-01 \\
7.5 \\
75\end{array}$ & $\begin{array}{l}28.8 \\
25.5 \\
22 \\
18.6 \\
14.9 \\
t \text { test }\end{array}$ & $\begin{array}{c}28.9 \\
25.5 \\
21.9 \\
18.6 \\
15.3 \\
0.98\end{array}$ \\
\hline Pythium ultimum (Pult Med\#2) & PultRPB & $\begin{array}{l}5.00 \mathrm{E}-04 \\
5.00 \mathrm{E}-03 \\
5.00 \mathrm{E}-02 \\
5.00 \mathrm{E}-01 \\
5\end{array}$ & $\begin{array}{l}33 \\
29.7 \\
26.2 \\
22.7 \\
19.6 \\
t \text { test }\end{array}$ & $\begin{array}{c}32.4 \\
29.2 \\
25.5 \\
22.2 \\
19.1 \\
0.87\end{array}$ \\
\hline E. carotovora (Ecc WPP14) & MpdEc & $\begin{array}{l}1.00 \mathrm{E}-02 \\
1.00 \mathrm{E}-01 \\
1 \\
10 \\
100\end{array}$ & $\begin{array}{l}36.5 \\
33.1 \\
29.6 \\
26 \\
23.3 \\
t \text { test }\end{array}$ & $\begin{array}{c}35.3 \\
32.9 \\
29.3 \\
24.8 \\
22.1 \\
0.76\end{array}$ \\
\hline S. tuberosum (tuber) & PotAct & $\begin{array}{l}5.10 \mathrm{E}-04 \\
5.10 \mathrm{E}-03 \\
5.10 \mathrm{E}-02 \\
5.10 \mathrm{E}-01 \\
5.1 \\
51\end{array}$ & $\begin{array}{l}33.76 \\
31.17 \\
28.47 \\
24.41 \\
21.54 \\
18.98\end{array}$ & \\
\hline
\end{tabular}

${ }^{a}$ Fisher $t$ test comparisons of standard curve amplifications in the presence and absence of potato DNA are indicated. 
TABLE 4. Amount of DNA (picograms) of five pathogens detected in $100 \mathrm{pg}$ of total DNA extracted from tubers inoculated individually 4 days postinoculation ${ }^{\mathrm{a}}$

\begin{tabular}{|c|c|c|c|c|c|}
\hline Tuber & Phytophthora infestans ${ }^{\mathrm{b}}$ & Phytophthora erythroseptica $^{\mathrm{c}}$ & 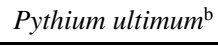 & Fusarium sambucinum ${ }^{\mathrm{b}}$ & Erwinia carotovora \\
\hline Tuber 1 & 2.29 & 2.16 & 4.71 & 1.80 & 4.85 \\
\hline Tuber 2 & 1.44 & 2.13 & 3.31 & 1.89 & 5.11 \\
\hline Tuber 3 & 2.11 & 2.10 & 3.88 & 1.31 & 5.38 \\
\hline Tuber 4 & 2.08 & 2.22 & 2.98 & 2.48 & 5.35 \\
\hline Tuber 5 & 2.23 & 2.16 & 3.97 & 1.83 & 5.53 \\
\hline Tuber 6 & 1.27 & 2.22 & 4.56 & 1.34 & 5.34 \\
\hline Tuber 7 & 2.23 & 2.19 & 4.80 & 0.69 & 5.11 \\
\hline Tuber 8 & 1.94 & 2.22 & 2.24 & 1.54 & 6.50 \\
\hline Tuber 9 & 1.82 & 2.22 & 3.52 & 1.39 & 6.58 \\
\hline Tuber 10 & 2.49 & 2.37 & 3.07 & 1.80 & 6.67 \\
\hline Tuber 11 & 2.46 & 2.46 & 2.80 & - & - \\
\hline Tuber 12 & 2.29 & 2.07 & 2.74 & 1.63 & - \\
\hline Healthy & $\mathrm{NA}^{\mathrm{e}}$ & NA & NA & NA & NA \\
\hline Healthy & NA & NA & NA & NA & NA \\
\hline
\end{tabular}

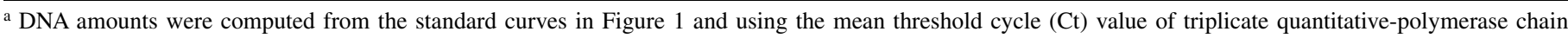
reaction amplifications.

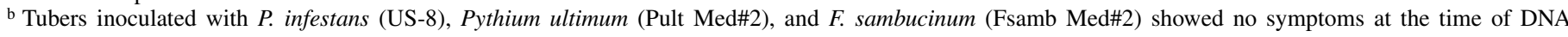
extraction, four days postinoculation.

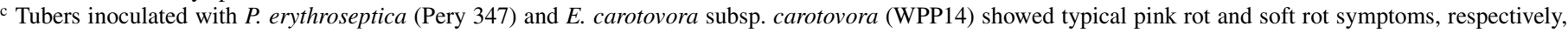
at the time of DNA extraction, 4 days postinoculation.

${ }^{\mathrm{d}}$ Healthy tubers were treated with distilled water and pathogen-free agar plug for Pythium ultimum.

e $\mathrm{NA}=$ no amplification.

TABLE 5. Detection and quantification of Phytophthora erythroseptica (pink rot), Pythium ultimum (leak), and Erwinia carotovora (soft rot) in naturally infected potato tubers collected in a storage facility in Almond, WI

\begin{tabular}{lcrccc}
\hline Sample & Control $^{\mathrm{a}}$ & $\Delta \mathrm{Ct}^{\mathrm{b}}$ & Pathogen $^{\mathrm{c}}(\mathrm{Ct})$ & Host $^{\mathrm{d}}(\mathrm{Ct})$ & $\mathrm{IC}^{\mathrm{e}}$ \\
\hline Leak1 & 28.9 & 1.1 & 26.8 & 21.1 & 0.8 \\
Leak2 & 26.7 & -1.1 & 26.1 & 20.9 & 0.8 \\
Leak3 & 27.4 & 0.4 & 24.5 & 20.6 & 0.8 \\
Leak4 & 26.3 & -1.5 & 26.2 & 22.8 & 0.9 \\
Leak5 & 26.9 & -0.9 & 34.3 & 27.5 & 0.8 \\
Leak6 & 27.9 & 0.1 & 35.4 & 24.9 & 0.7 \\
Leak7 & 27.5 & -0.3 & 18.9 & 21.5 & 1.1 \\
Leak8 & 28.9 & 1.1 & 21.2 & 21.0 & 1.0 \\
Softrot1 & 27.4 & -0.4 & 19.7 & 21.7 & 1.1 \\
Softrot2 & 27.0 & -0.8 & 20.3 & 21.1 & 1.0 \\
Softrot3 & 27.1 & -0.7 & 20.6 & 23.0 & 1.1 \\
Softrot4 & 27.1 & -0.7 & 20.9 & 19.9 & 1.0 \\
Softrot5 & 26.8 & -1.0 & 20.0 & 22.8 & 1.1 \\
Softrot6 & 27.3 & -0.5 & 21.4 & 19.8 & 0.9 \\
Softrot7 & 28.3 & 0.5 & 32.8 & 21.6 & 0.7 \\
Softrot8 & 27.3 & -0.5 & 25.2 & 20.2 & 0.8 \\
Pinkrot1 & 27.0 & -0.8 & 24.3 & 27.6 & 1.1 \\
Pinkrot2 & 27.1 & -0.7 & 29.6 & 31.4 & 1.1 \\
Pinkrot3 & 26.7 & -1.1 & 25.5 & 25.2 & 1.0 \\
Pinkrot4 & 27.2 & -0.6 & 25.0 & 25.3 & 1.0 \\
Pinkrot5 & 27.1 & -0.7 & 28.1 & 20.4 & 0.7 \\
Pinkrot6 & 26.9 & -0.9 & 22.1 & 24.6 & 1.1 \\
Pinkrot7 & 27.6 & -0.2 & - & 20.9 & - \\
Pinkrot8 & 27.8 & 0.0 & 23.3 & 22.8 & 1.0 \\
Control ${ }^{\mathrm{f}}$ & 27.8 & - & - & - & - \\
\hline Thresh & & -1.9 & \\
\hline
\end{tabular}

a Threshold cycle $(\mathrm{Ct})$ values using $P$. infestans DNA (2 pg) added to each sample DNA to test for the lack of polymerase chain reaction inhibitors.

${ }^{\mathrm{b}} \Delta \mathrm{Ct}=\mathrm{Ct}_{\text {sample }}-\mathrm{Ct}_{\text {control }}$.

${ }^{c} \mathrm{Ct}$ values obtained using primers PultRPB-F/PultRPB-R (leak), MpdEcF/MpdEc-R (soft rot), and PeryRPB-F/PeryRPB-R (pink rot).

${ }^{\mathrm{d}} \mathrm{Ct}$ values obtained using primers PotAct-F/PotAct-R.

e Infection coefficient: $\mathrm{IC}=\mathrm{Ct}_{\text {host }} / \mathrm{Ct}_{\text {pathogen }}$.

f Two picograms of $P$. infestans DNA from pure culture, in the absence of host DNA.

The primer pairs developed in this study could be used for the diagnosis of potato diseases in the field and storage facilities. In laboratory-inoculated tubers, we were able to detect the presence of $P$. infestans, Pythium ultimum, and F. sambucinum prior to symptom appearance, while $P$. erythroseptica and E. carotovora were detected at the appearance of the first symptoms on inoculated tubers. We have also used the primers to detect the presence of individual pathogens in mixed infections of pink rot, leak, and soft rot. While pathogen isolation on culture media only detected the soft rotting bacteria, Q-PCR revealed the presence of P. erythroseptica and Pythium ultimum (data not shown).

The methodology described in this study may allow for the development of models to predict the fate of crops prior to harvest, where decisions regarding the storage duration would be based on the amount of DNA detected. By incorporating a quantification of phytopathogen amounts on/in potato tubers, a triage based on risk potential becomes possible. This in turn is expected to allow for substantial reductions in postharvest pesticide applications, particularly in crops exhibiting low pathogen amounts. Nevertheless, a model for the prediction of tuber storability is not yet available and necessitates several growing and storage seasons to develop. Furthermore, studies to identify the most appropriate sampling methodologies at the field and tuber levels are not yet available and will be productive opportunities for future research.

\section{ACKNOWLEDGMENTS}

This study was supported by grants from the Wisconsin Potato and Vegetable Growers Association and the USDA-ARS Potato Research Program. We thank A. Charkowski, F. Martin, P. Tooley, K. O’Donnell, M. Nakhla, J. Miller, C. Grau, G. Jung, D. Rouse, and J. Helgeson for providing isolates and/or DNA used in this study; F. Martin, J. Leslie, and A. Charkowski for reviews and suggestions that have helped in improving this manuscript; M. Hibbing for contribution of Erwinia spp. sequences; R. Reedy for technical input; R. E. Rand for assistance in all tuber inoculations; and the senior editor and anonymous reviewers of Phytopathology for helping improve this manuscript.

\section{LITERATURE CITED}

1. Anonymous. 2002. National Potato Council 2002-2003 Potato Statistical Yearbook. N. P. Council, ed. Washington D.C.

2. Carbone, I., and Kohn, L. M. 1999. A method for designing primer sets for speciation studies in filamentous Ascomycetes. Mycologia 91:553-556.

3. Cochran, W. G., and Cox, G. M. 1957. Experimental Designs. 2nd ed. John Wiley \& Sons, New York.

4. Cooke, D. E. L., Drenth, A., Duncan, J. M., Wagels, G., and Brasier, C. M. 2000. A molecular phylogeny of Phytophthora and related Oomycetes. Fungal Gen. Biol. 30:17-32.

5. Cooke, D. E. L., and Duncan, J. M. 1997. Phylogenetic analysis of Phytophthora species based on ITS1 and ITS2 sequences of the ribosomal RNA gene repeat. Mycol. Res. 101:667-677.

6. Cullen, D. W., Lees, A. K., Toth, I. K., and Duncan, J. M. 2001. Conventional PCR and real-time quantitative PCR detection of Helminthosporium solani in soil and on potato tubers. Eur. J. Plant Pathol. 107:387-398. 
7. Cullen, D. W., Lees, A. K., Toth, I. K., and Duncan, J. M. 2002. Detection of Colletotrichum coccodes from soil and potato tubers by conventional and quantitative real-time PCR. Plant Pathol. 51:281-292.

8. Erwin, D. C., and Ribeiro, O. K. 1996. Phytophthora Diseases Worldwide. The American Phytopathological Society, St. Paul, MN.

9. Fan, L., Song, J., Hildebrand, P. D., and Forney, C. F. 2002. Interaction of ozone and negative air ions to control micro-organisms. J. Appl. Microbiol. 93:144-148.

10. Gao, X., Jackson, T. A., Lambert, K. N., Li, S., Hartman, G. L., and Niblack, T. L. 2004. Detection and quantification of Fusarium solani $\mathrm{f}$. sp. glycines in soybean roots with real-time quantitative polymerase chain reaction. Plant Dis. 88:1372-1380.

11. Glass, N. L., and Donaldson, G. C. 1995. Development of primer sets designed for use with the PCR to amplify conserved genes from filamentous Ascomycetes. Appl. Environ. Microbiol. 61:1323-1330.

12. Hall, T. A. 1999. BioEdit: A user friendly biological sequence alignment editor and analysis program for Windows 95/98/NT. Nucleic Acid Symposium Series 41:95-98.

13. Jimenez-Gasco, M. M., Milgroom, M. G., and Jimenez-Diaz, R. M. 2002. Gene genealogies support Fusarium oxysporum f. sp. ciceris as a monophyletic group. Plant Pathol. 51:72-77.

14. Ko, K. S., and Jung, H. S. 2002. Three nonorthologous ITS1 types are present in a polypore fungus Trichaptum abietinum. Mol. Phylogenet. Evol. 23:112-122.

15. Lambert, D. H., and Salas, B. 2001. Pink rot. Page 106 in: Compendium of Potato Diseases. 2nd ed. W. R. Stevenson, R. Loria, G. D. Franc, and D. P. Weingartner, eds. The American Phytopathological Society, St. Paul, MN.

16. Lees, A. K., Cullen, D. W., Sullivan, L., and Nicolson, M. J. 2002. Development of conventional and quantitative real-time PCR assays for the detection and identification of Rhizoctonia solani AG-3 in potato and soil. Plant Pathol. 51:293-302.

17. Martin, F. N., and Tooley, P. W. 2003. Phylogenetic relationships among Phytophthora species inferred from sequence analysis of mitochondrially encoded cytochrome oxidase I and II genes. Mycologia 95:269-284.

18. Mitchell, D. J. 1978. Relationships of inoculum levels of several soilborne species of Phytophthora and Pythium to infection of several hosts. Phytopathology 68:1754-1759.

19. Mitchell, D. J., Kannwischer, M. E., and Moore, E. S. 1978. Relationship of numbers of zoospores of Phytophthora cryptogea to infection and mortality of watercress. Phytopathology 68:1446-1448.

20. Olsen, N. L., Kleinkopf, G. E., and Woodell, L. K. 2003. Efficacy of chlorine dioxide for disease control on stored potatoes. Am. J. Potato Res. 80:387-395.

21. Paris, R., and Lamattina, L. 2002. Increased ratio of mitochondrial rDNA to cytoplasmic rDNA during zoosporic and germinating cyst stages of the life cycle of Phytophthora infestans (Mont.) de Bary. Can. J. Microbiol. 48:268-274.

22. Porter, L. D., and Johnson, D. A. 2004. Survival of Phytophthora infestans in surface water. Phytopathology 94:380-387.

23. Powelson, M. L., and Franc, G. D. 2001. Blackleg, aerial stem rot, and tuber soft rot. Pages 10-11 in: Compendium of Potato Diseases. 2nd ed. W. R. Stevenson, R. Loria, G. D. Franc, and D. P. Weigartner, eds. The American Phytopathological Society, St. Paul, MN.

24. Ristaino, J. B., Madritch, M., Trout, C. L., and Parra, G. 1998. PCR amplification of ribosomal DNA for species identification in the plant pathogen genus Phytophthora. Appl. Environ. Microbiol. 64:948-954.
25. Rozen, S., and Skaletsky, H. 2000. Primer3 on the WWW for general users and for biologist programmers. Pages 365-386 in: Bioinformatics Methods and Protocols: Methods in Molecular Biology. S. Krawetz and S. Misener, eds. Humana Press, Totowa, NJ.

26. Salas, B., and Secor, G. A. 2001. Leak. Pages 30-31 in: Compendium of Potato Diseases. 2nd ed. W. R. Stevenson, R. Loria, G. D. Franc, and D. P. Weigartner, eds. The American Phytopathological Society, St. Paul, MN.

27. Schweigkofler, W., O'Donnell, K., and Garbelotto, M. 2004. Detection and quantification of airborne conidia of Fusarium circinatum, the causal agent of pine pitch canker, from two California sites by using a real-time PCR approach combined with a simple spore trapping method. Appl. Environ. Microbiol. 70:3512-3520.

28. Secor, G. A., and Salas, B. 2001. Fusarium dry rot and Fusarium wilt Pages 23-25 in: Compendium of Potato Diseases. 2nd ed. W. R. Stevenson, R. Loria, G. D. Franc, and D. P. Weingartner, eds. The American Phytopathological Society, St. Paul, MN.

29. Stiller, J. W., and Hall, B. D. 1997. The origin of red algae: Implications for plasmid evolution. Proc. Natl. Acad. Sci. 94:4520-4525.

30. Thompson, J. D., Gibson, T. J., Plewniak, F., Jeanmougin, F., and Higgins, D. G. 1997. The CLUSTAL X windows interface: Flexible strategies for multiple sequence alignment aided by quality analysis tools. Nucleic Acids Res. 25:4876-4882.

31. Thompson, J. D., Higgins, D. G., and Gibson, T. J. 1994. Clustal W improving the sensitivity of progressive multiple sequence alignment through sequence weighting, position-specific gap penalties and weight matrix choice. Nucleic Acids Res. 22:4673-4680.

32. Tooley, P. W., Bunyard, B. A., Carras, M. M., and Hatziloukas, E. 1997. Development of PCR primers from internal transcribed spacer region 2 for detection of Phytophthora species infecting potatoes. Appl. Environ. Microbiol. 63:1467-1475.

33. Tooley, P. W., Carras, M. M., and Lambert, D. H. 1998. Application of a PCR-based test for detection of potato late blight and pink pot in tubers. Am. J. Potato Res. 75:187-194.

34. Trout, C. L., Ristaino, J. B., Madritch, M., and Wangsomboondee, T. 1997. Rapid detection of Phytophthora infestans in late blight-infected potato and tomato using PCR. Plant Dis. 81:1042-1048.

35. Tsai, L. S., Huxsoll, C. C., and Robertson, G. 2001. Prevention of potato spoilage during storage by chlorine dioxide. J. Food Sci. 66:472-477.

36. Valsesia, G., Gobbin, D., Patocchi, A., Vecchione, A., Pertot, I., and Gessler, C. 2005. Development of a high-throughput method for quantification of Plasmopara viticola DNA in grapevine leaves by means of quantitative real-time polymerase chain reaction. Phytopathology 95:672-678.

37. Wen, K., Seguin, P., St-Arnaud, M., and Jabaji-Hare, S. 2005. Real-time quantitative RT-PCR of defense-associated gene transcripts of Rhizoctonia solani-infected bean seedlings in response to inoculation with a nonpathogenic binucleate Rhizoctonia isolate. Phytopathology 95:345-353.

38. Winton, L. M., Manter, D. K., Stone, J. K., and Hansen, E. A. 2003. Comparison of biochemical, molecular, and visual methods to quantify Phaeocryptopus gaeumannii in Douglas-Fir foliage. Phytopathology 93:121-126.

39. Winton, L. M., Stone, J. K., Watrud, L. S., and Hansen, E. M. 2002. Simultaneous one-tube quantification of host and pathogen DNA with real-time polymerase chain reaction. Phytopathology 92:112-116.

40. Zuker, M., Mathews, D. H., and Turner, D. H. 1999. Algorithms and Thermodynamics for RNA Secondary Structure Prediction: A Practical Guide in RNA Biochemistry and Biotechnology. J. Barciszewski and B. F. C. Clark, eds. Kluwer Academic Publishers, Dordrecht, the Netherlands. 